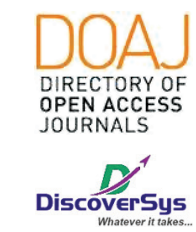

Published by DiscoverSys

\section{Interferensi sampel lipemik pada bayi dengan lipemia retinalis dikarenakan primary mixed hyperlipidemia: laporan kasus}

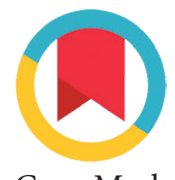

CrossMark

\author{
Andi Munawirah, ${ }^{*}{ }^{*}$ Habibah Setya Muhiddin, ${ }^{2}$ Liong Boy Kurniawan, ${ }^{3}$ Ruland DN Pakasi ${ }^{3}$
}

\section{ABSTRACT}

Background: Interference is a condition of which sample components cause an error in the analyte measurement in the analyzer. The most common cause of interference is lipemic sample. Lipemic sample is characterized by turbidity of the serum or plasma caused by an accumulation of lipoprotein particles. Primary mixed hyperlipidemia (PMH) is a cause of primary hypertrigliseridemia with lipemia manifestation.

Case report: A three month-old baby boy was admitted to a hospital, having white spots in his black eyes. The spots were seen clearer at light exposure, and ophthalmologic examination indicated lipemia retinalis. Patient's sample was lipemic and its laboratory analysis

resulted in as follow: WBC 13.103/ $/ \mathrm{L}, \mathrm{Hb} 15.6 \mathrm{gr} / \mathrm{dL}, \mathrm{RBC} 2.99106 / \mu \mathrm{L}$, triglyserida $10.435 \mathrm{mg} / \mathrm{dL}$, total cholesterol $631 \mathrm{mg} / \mathrm{dL}, \mathrm{HDL} 12 \mathrm{mg} / \mathrm{dL}$, LDL $195 \mathrm{mg} / \mathrm{dL}$, and apoprotein B $196 \mathrm{mg} / \mathrm{dL}$. Due to a significant interference, SGOT, SGPT, ureum and creatinin were not obtained. Immunologic serum analysis of the patient and his mother showed an increasing of antibody lg G CMV: 28 dan $20 \mathrm{lU} / \mathrm{ml}$, respectively.

Conclusion: Lipemic samples could directly affect most of laboratory examination methods. Laboratory results with such lipemia interferences shoud be interpretated critically and accurately to produce precise diagnosis, and in turn, monitoring of patient with lipemia.

Keywords: hyperlipidemia, interference, lipemia retinalis, lipemic sample, primary mixed.

Cite This Article: Munawirah, A., Muhiddin, H.S., Kurniawan, L.B., Pakasi, R.D.N. 2019. Interferensi sampel lipemik pada bayi dengan lipemia retinalis dikarenakan primary mixed hyperlipidemia: Iaporan kasus. Intisari Sains Medis 10(2): 413-419. D0I: 10.15562/ism.v10i2.370

\title{
ABSTRAK
}

'Program Pendidikan Dokter Spesialis Patologi Klinik Fakultas Kedokteran Universitas Hasanuddin, Rumah Sakit Umum Pusat dr. Wahidin Sudirohusodo, Makassar

${ }^{2}$ Departemen IImu Kesehatan Mata Fakultas Kedokteran Universitas Hasanuddin, Rumah Sakit Umum Pusat dr. Wahidin Sudirohusodo, Makassar ${ }^{3}$ Departemen Ilmu Patologi Klinik Fakultas Kedokteran Universitas Hasanuddin, Rumah Sakit Umum Pusat dr. Wahidin Sudirohusodo, Makassar

\section{*Koresponden:}

Andi Munawirah; Program

Pendidikan Dokter Spesialis

Patologi Klinik Fakultas Kedokteran Universitas Hasanuddin, Rumah

Sakit Umum Pusat dr. Wahidin

Sudirohusodo, Makassar,

m13_r4@yahoo.com

Diterima: 16-11-2018

Disetujui: 13-05-2019

Diterbitkan: 01-08-2019
Pendahuluan: Interferensi adalah suatu kondisi terdapatnya komponen di dalam sampel pasien yang dapat menyebabkan kesalahan pengukuran analit tertentu oleh alat pengukur. Salah satu penyebab utama terjadinya interferensi adalah sampel yang lipemik. Sampel lipemik merupakan sampel serum atau plasma yang keruh akibat akumulasi partikel lipoprotein. Primary mixed hyperlipidemia (PMH) merupakan salah satu penyakit hipertrigliserida primer dengan manifestasi sampel darah yang lipemik.

Kasus : Seorang bayi laki-laki usia 3 bulan, datang ke rumah sakit dengan keluhan bercak berwarna putih pada mata hitam dan lebih jelas terlihat jika terkena cahaya. Pemeriksaan oftalmologik menunjukkan adanya lipemia retinalis. Sampel pasien menunjukkan gambaran lipemik dengan hasil laboratorium leukosit $13.10^{3} / \mu \mathrm{L}$, hemoglobin $15.6 \mathrm{gr} / \mathrm{dL}$, eritrosit $2.9910^{6} / \mu \mathrm{L}$, trigliserida $10.435 \mathrm{mg} / \mathrm{dL}$, kolesterol total $631 \mathrm{mg} / \mathrm{dL}$, HDL $12 \mathrm{mg} / \mathrm{dL}$, LDL $195 \mathrm{mg} / \mathrm{dL}$ dan apoprotein B 196 mg/dL. Hasil SGOT, SGPT, ureum, dan kreatinin tidak didapatkan karena adanya interferensi yang signifikan. Pemeriksaan imunologik pada pasien dan ibunya menunjukkan peningkatan antibodi lgG CMV yaitu $28 \mathrm{IU} / \mathrm{ml}$ dan $20 \mathrm{IU} / \mathrm{ml}$. Profil lipid orang tua pasien menunjukkan hasil normal.

Kesimpulan:Sampel lipemik dapat menginterferensi berbagai metode pemeriksaan laboratorium. Hasil laboratorium dengan interferensi sampel lipemik ini perlu diinterpretasi secara kritis dan tepat sehingga dapat menunjang diagnosis dan pemantauan pasien yang tepat pula.

Kata kunci : hyperlipidemia, interferensi, lipemia retinalis, primary mixed, sampel lipemik.

Cite Pasal Ini: Munawirah, A., Muhiddin, H.S., Kurniawan, L.B., Pakasi, R.D.N. 2019. Interferensi sampel lipemik pada bayi dengan lipemia retinalis dikarenakan primary mixed hyperlipidemia: laporan kasus. Intisari Sains Medis 10(2): 413-419. D0I: 10.15562/ism.v10i2.370

\section{PENDAHULUAN}

Interferensi adalah suatu kondisi terdapatnya komponen di dalam sampel pasien yang dapat menyebabkan kesalahan pengukuran analit tertentu oleh alat pengukur. Salah satu penyebab utama terjadinya interferensi adalah sampel lipemik. Sampel lipemik merupakan sampel serum atau plasma yang keruh akibat akumulasi partikel lipoprotein, terutama kilomikron dan very low density lipoprotein (VLDL), sehingga sampel tampak berwarna seperti susu., ${ }^{1,2}$ 
Sampel lipemik paling sering disebabkan oleh puasa yang tidak adekuat sebelum pengambilan sampel dan hipertrigliserida. Hipertrigliserida terdiri atas hipertrigliserida primer dan sekunder. Hipertrigliseridemia primer disebabkan oleh defek genetik sehingga metabolisme trigliserida terganggu seperti hiperlipidemia Fredrickson tipe I, IV, dan V, sedangkan hipertrigliseridemia sekunder disebabkan konsumsi alkohol, obesitas, sindrom metabolik, diabetes melitus tipe 2, dan obat-obatan..$^{3-5}$

Sampel lipemik dapat menginterferensi beberapa metode pemeriksaan melalui tiga cara yaitu pengurangan fraksi aqueos pada sampel, partitioning, dan gangguan transmisi cahaya, yang kemudian dapat mempengaruhi hasil pemeriksaan laboratorium. Hasil laboratorium dengan interferensi sampel lipemik memerlukan interpretasi secara kritis dan tepat sehingga dapat menunjang diagnosis dan penanganan pasien yang tepat pula. ${ }^{1,2}$

Primary mixed hyperlipidemia (PMH) atau hiperlipidemia Fredrickson tipe V adalah kelainan metabolisme lipid dengan karakteristik peningkatan kilomikron dan VLDL. PMH merupakan penyakit autosomal dominan, meskipun dasar genetiknya belum sepenuhnya diketahui. ${ }^{5-8}$

Peningkatan kilomikron dan VLDL pada penyakit ini menyebabkan terjadinya hipertrigliserida yang berat dan kemudian terakumulasi pada darah dan organ lain. Akumulasi trigliserida dalam darah dapat dilihat pada serum pasien yang tampak seperti susu, "milky appeareance", dan dalam istilah laboratoriumnya disebut sebagai sampel lipemik. Akumulasi trigliserida pada organ lain seperti pada kulit berupa eruptif xantomas, dan pada pembuluh darah retina berupa lipemia retinalis. ${ }^{6,9,10}$

Laporan kasus ini ditujukan untuk mengkaji interferensi laboratorium yang disebabkan oleh sampel lipemik pada pasien bayi dengan lipemia retinalis dikarenakan kecurigaan Primary Mixed Hyperlipidemia.

\section{DESKRIPSI KASUS}

\section{Anamnesis}

Pada saat anamnesis diketahui bahwa seorang bayi laki-laki, usia 3 bulan, datang ke poliklinik mata rumah sakit dengan keluhan bercak berwarna putih pada mata hitam mata kanan sejak sekitar 2 minggu yang lalu, warna putih pada mata lebih jelas terlihat jika terkena cahaya, dan tampak seperti mata kucing. Riwayat mata merah tidak ada. Riwayat kelahiran: lahir di rumah sakit, persalinan ditolong oleh dokter. Pasien lahir pada usia kehamilan 31 minggu (kurang bulan), berat badan lahir 1700 gram. Riwayat pemeriksaan antenatal tidak ada, riwayat abortus tidak ada.

\section{Pemeriksaan Fisis}

Pada pemeriksaan fisik, keadaan umu tampak sakit sedang, komposmentis dengan gizi baik. Tekanan darah 110/60 mmH, nadi $110 \mathrm{kali} /$ menit, pernapasan $20 \mathrm{kali} /$ menit dan suhu 36.6 c. Pada pemeriksaan general dari kepala, leher, thorax, abdomen, dan ekstremitas tidak ditemukan adanya kelainan.

\section{Pemeriksaan Oftalmologi}

Hasil pemeriksaan oftalmologi didapatkan pada mata kanan tidak ada persepsi cahaya dan pada mata kiri masih ada persepsi cahaya. Segmen anterior kedua mata dalam batas normal. Pupil mata kanan dilatasi, refleks cahaya (-) dan pupil mata kiri dilatasi, refleks cahaya (+). Pemeriksaan funduskopi menunjukkan papil optik batas tegas, Cup Disk Ratio (CDR) kesan normal, arteri dan vena berwarna putih dan retina perifer kesan salmon pink appereance. Klinis mata pasien dapat dilihat pada Gambar 1 A-B.

\section{Pemeriksaan Laboratorium}

Sampel darah pasien dapat dilihat pada Gambar 1 C. Pada Tabel 1. dapat dilihat hasil pemeriksaan complete blood count. Dari hasil tersebut, didapatkan kesan nilai $\mathrm{Hb}, \mathrm{MCH}, \mathrm{MCHC}$ meningkat palsu disertai trombositosis.

Pada Tabel 2. disajikan data hasil pemeriksaan kimia darah. Pada pemeriksaan tersebut didapatkan kesan hipertrigliseridemia sangat berat, hiperkolesterolemia, peningkatan LDL dan apolipoprotein B. Hasil pemeriksaan SGOT, SGPT, ureum, dan

A

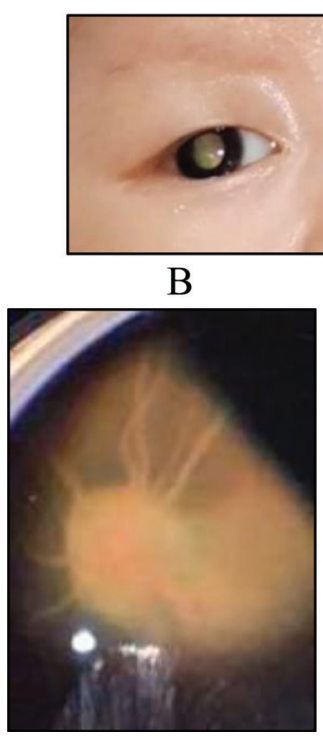

Gambar 1

(A) Gambaran klinis pasien; (B) Gambaran lipemia retinalis pada funduskopi; (C) Sampel pasien menunjukkan serum sangat lipemik seperti susu 
Tabel 1 Hasil pemeriksaan complete blood count

\begin{tabular}{lcc}
\hline Parameter & Hasil & Nilai Rujukan \\
\hline Hemoglobin $(\mathrm{g} / \mathrm{dL})$ & 15.6 & $10.4-16.0$ \\
Hematokrit $(\%)$ & 25.9 & $35-51$ \\
Eritrosit $\left(10^{6} / \mu \mathrm{L}\right)$ & 2.99 & $3.65-5.05$ \\
$\mathrm{MCV}(\mathrm{fL})$ & 86.6 & $83.0-107.0$ \\
$\mathrm{MCH}(\mathrm{pg})$ & 52.2 & $25.0-35.0$ \\
$\mathrm{MCHC}(\mathrm{g} / \mathrm{dL})$ & 60.2 & $32.0-36.0$ \\
$\mathrm{RDW}-\mathrm{CV}$ & 15.7 & $11.5-14.5$ \\
Leukosit $\left(10^{3} / \mu \mathrm{L}\right)$ & 13 & $5.5-17.50$ \\
Trombosit $\left(10^{3} / \mu \mathrm{L}\right)$ & 607 & $150-450$ \\
\hline
\end{tabular}

Tabel 2 Hasil pemeriksaan kimia darah

\begin{tabular}{lcc}
\hline Parameter & Hasil & Nilai rujukan \\
\hline Kolesterol total & 631 & $<200(\mathrm{mg} / \mathrm{dL})$ \\
HDL & 12 & $>55(\mathrm{mg} / \mathrm{dL})$ \\
LDL & 195 & $<130(\mathrm{mg} / \mathrm{dL})$ \\
Trigliserida & 10,435 & $30-100(\mathrm{mg} / \mathrm{dL})$ \\
Apoprotein B & 196 & $96-112(\mathrm{mg} / \mathrm{dL})$ \\
\hline
\end{tabular}

Tabel 3 Hasil pemeriksaan imunologi

\begin{tabular}{lccc}
\hline Parameter & Bayi & Ibu & Nilai rujukan \\
\hline Toxoplasma IgM & 0.06 & 0.06 & $<0.65 \mathrm{COI}$ \\
Toxoplasma IgG & 0 & 0 & $<8 \mathrm{IU} / \mathrm{ml}$ \\
Rubella IgM & 0.07 & 0.47 & $<0.9 \mathrm{COI}$ \\
Rubella IgG & 0 & 0 & $<6 \mathrm{IU} / \mathrm{ml}$ \\
CMV IgM & 0.49 & 0.09 & $<1.2 \mathrm{COI}$ \\
CMV IgG & 28 & 20 & $<14 \mathrm{IU} / \mathrm{ml}$ \\
\hline
\end{tabular}

Tabel 4 Pemeriksaan profil lipid orang tua pasien

\begin{tabular}{lccc}
\hline Parameter & lbu & Bapak & Nilai Rujukan \\
\hline Kolesterol total (mg/dl) & 188 & 206 & $<200$ \\
HDL (mg/dl) & 42 & 43 & $>55$ \\
LDL (mg/dl) & 131 & 143 & $<130$ \\
Trigliserida (mg/dl) & 75 & 99 & $30-100$ \\
\hline
\end{tabular}

kreatinin tidak didapatkan karena interferensi sampel lipemik.

Pada Tabel 3. dapat dilihat bahwa terdapat peningkatan antibodi IgG CMV pada bayi dan ibu. Pada Tabel 4. Disajikan data profil lipid pada orang tua pasien, dengan kesan normal.

Pemeriksaan darah rutin pasien diperiksa menggunakan alat sysmex XT dengan metode cyanmethemoglobin, pemeriksaan kimia darah dilakukan dengan metode spektrofotometer menggunakan alat ABX Pentra 400, untuk parameter
SGOT, SGPT, ureum, dan kreatinin juga diperiksa menggunakan Cobas 6000 Roche, dan pemeriksaan imunologi menggunakan alat Imunologi Vidas dengan metode Enzyme Linked Fluorescent Assay (ELFA).

\section{Diagnosis}

Berdasarkan parameter laboratorium maupun anamnesis dan pemeriksaan fisik yang dijabarkan pada studi di atas maka pasien ini didiagnosis dengan ODS/ lipemia retinalis et kausa suspek Primary Mixed Hyperlipidemia

\section{PEMBAHASAN}

Primary mixed hiperlipidemia (PMH) atau hiperlipidemia tipe $\mathrm{V}$ adalah bentuk kelainan metabolisme lipid dengan karakteristik peningkatan kilomikron dan VLDL. Insiden dislipoproteinemia tipe ini adalah 1 dari 1000 kasus, biasanya terjadi pada usia dewasa, meskipun beberapa kasus telah dilaporkan terjadi pada anak dan bayi. ${ }^{8,12}$

Seorang bayi laki-laki usia 3 bulan, masuk rumah sakit dengan keluhan bercak putih pada mata hitam mata kanan. Riwayat mata merah tidak ada. Pemeriksaan oftalmologi menunjukkan adanya gambaran salmon pink appereance. Sampel serum pasien menunjukkan sampel yang lipemik. Hasil pemeriksaan laboratorium menunjukkan hipertrigliseridemia yang sangat berat, hiperkolesterolemia, penurunan HDL, peningkatan LDL dan apolipoprotein B. Berdasarkan anamnesis, pemeriksaan oftalmologi dan pemeriksaan laboratorium maka pasien didiagnosis dengan lipemia retinalis suspek kausa Primary Mixed Hyperlipidemia (PMH).

Manifestasi klinis PMH dapat berupa adanya sampel lipemik pada serum pasien, lipemia retinalis, eruptif xanthomas pada kulit, hepatomegali dan pada kondisi yang serius dapat terjadi pankreatitis. Pada pasien ini ditemukan adanya sampel serum yang lipemik dan adanya lipemia retinalis. Serum yang lipemik merupakan penanda peningkatan kilomikron dan atau VLDL. Kilomikron merupakan lipoprotein dengan ukuran yang paling besar yaitu sekitar 70 - $1000 \mathrm{~nm}$ dibandingkan dengan lipoprotein lainnya seperti VLDL $(27-200 \mathrm{~nm})$, LDL (20 - $26 \mathrm{~nm})$ dan HDL ( $6-12.5 \mathrm{~nm})$, sehingga peningkatan kilomikron dan VLDL sangat memungkinkan untuk menyebabkan sampel lipemik., ${ }^{9,13}$

Sampel lipemik dapat menginterferensi berbagai pemeriksaan laboratorium melalui tiga cara yaitu pengurangan persentase fraksi aqueous pada sampel, partitioning, dan gangguan pada transmisi cahaya. Sampel lipemik merupakan peningkatan konsentrasi lipoprotein yang mengurangi 
presentasi fraksi aqueous pada sampel. Fraksi lipid (non-aqueous) pada sampel normal adalah sekitar $7 \%$. Persentase fraksi lipid pada sampel lipemik meningkat dan mengurangi fraksi aqueous. Hal ini kemudian akan berpengaruh pada analit yang larut dalam fraksi aqueous seperti natrium, kalium, dan klorida pada pemeriksaan elektrolit.

Beberapa analit non polar seperti homon steroid dan obat-obatan lipofilik seperti dilantin dan fenobarbital dapat tergabung ke dalam fraksi non polar serum termasuk di dalamnya kilomikron dan VLDL. Penanganan sampel lipemik dengan teknik ekstraksi fraksi lipid atau partitioning dapat menyebabkan kesalahan pengukuran pada analit non polar tersebut.,214

Interferensi yang paling sering terjadi adalah gangguan pada transmisi cahaya. Sampel lipemik menyebabkan cahaya yang ditransmisikan akan terpendar sehingga pemeriksaan dengan metode nefelometri dan turbidimetri akan mengalami interferensi. Sampel lipemik juga dapat mengabsorbsi sejumlah cahaya yang secara proporsional berkebalikan dengan panjang gelombang yang diteruskan. Absorbsi cahaya pada sampel lipemik relatif rendah pada panjang gelombang $700 \mathrm{~nm}$, namun meningkat secara linear hingga pada panjang gelombang $500 \mathrm{~nm}$. Peningkatan absorbsi ini meningkat dengan cepat di antara panjang gelombang $500 \mathrm{~nm}$ hingga $320 \mathrm{~nm}$. Oleh karena itu, metode spektrofotometri mengalami interferensi terutama pada pemeriksaan yang menggunakan panjang gelombang yang lebih kecil.

Pemeriksaan hemoglobin pada pasien ini menggunakan metode spektrofotometer $(540 \mathrm{~nm})$ dan menunjukkan interferensi pada kadar trigliserida di atas $290 \mathrm{mg} / \mathrm{dL}$. Peningkatan trigliserida pada pasien lebih dari 35 kali melebihi limitasi interferensi alat. Metode pemeriksaan jumlah eritrosit adalah flowcytometri. Metode ini tidak mengalami interferensi akibat sampel lipemik. Hasil pemeriksaan darah rutin pasien menunjukkan hemoglobin $15.6 \mathrm{~g} / \mathrm{dL}$ dengan jumlah eritrosit $2.9910^{6} / \mu \mathrm{L}$. Ketidaksesuaian hemoglobin dan jumlah eritrosit dapat menunjukkan adanya interferensi pada kadar hemoglobin. Interferensi sampel lipemik dapat menyebabkan adanya peningkatan palsu kadar hemoglobin. Oleh karena itu, kadar hemoglobin pasien yang sesungguhnya diduga di bawah 15.6 $\mathrm{g} / \mathrm{dL}$. Interferensi ini juga berpengaruh terhadap parameter lain yang berhubungan dengan kadar hemoglobin seperti Mean Corpuscular Hemoglobin $(\mathrm{MCH})$ dan Mean Corpuscular Hemoglobin Consentration (MCHC). ${ }^{15}$

$\mathrm{MCH}$ adalah rerata konsentrasi hemoglobin per eritrosit. Pengukuran MCH dapat menunjukkan hasil peningkatan palsu pada hiperlipidemia.
MCHC menunjukkan rerata kadar hemoglobin per unit volume eritrosit. Nilai $\mathrm{MCH}$ tergantung pada keakuratan pengukuran hemoglobin dan hematokrit. Peningkatan palsu pada pengukuran hemoglobin juga akan menunjukkan peningkatan palsu pada nilai MCHC. ${ }^{15}$

Studi kasus Andrade dkk yang membandingkan pemeriksaan jumlah eritrosit, hemoglobin, dan indeks eritrosit pada pasien dengan hipertrigliserida berat sebelum dan sesudah dilakukan koreksi plasma menggunakan larutan salin menunjukkan bahwa jumlah eritrosit merupakan parameter yang paling stabil dengan bias $0.002 \%$ dibandingkan parameter lainnya seperti hemogobin yang mengalami peningkatan palsu sekitar 32 $\%$ dan indeks eritrosit juga meningkat palsu sekitar $15-32 \%{ }^{1}$

Hasil darah rutin pasien menunjukkan peningkatan trombosit yaitu $607.10^{3} / \mu \mathrm{L}$. Trombosistosis dapat terjadi secara primer maupun sekunder. Adanya penyakit dasar mengarahkan pada terjadinya trombositosis reaktif. Trombositosis reaktif terjadi karena produksi berlebih dari sitokin proinflamasi seperti IL-1, IL-6, dan IL-11 yang muncul pada inflamasi kronik, infektif, dan keganasan. Lipid berperan pada sistem metabolik dan juga inflamasi. Kelainan metabolik akibat multifaktor juga memicu terjadinya proses inflamasi, termasuk hiperlipidemia yang kemudian akan melepaskan sitokin inflamasi seperti IL-1 dan IL-6 yang memicu trombopoiesis sehingga terjadi trombositosis. ${ }^{15,16}$

Hasil laboratorium pasien menunjukkan trigliserida $10.435 \mathrm{mg} / \mathrm{dl}$, kolesterol total $631 \mathrm{mg} / \mathrm{dl}$, HDL 12 mg/dl, LDL 195 mg/dl, apoB 196 mg/dl $(1.96 \mathrm{~g} / \mathrm{l})$. Rasio hipertrigliserida terhadap apoB adalah 53.23. Rasio hipertrigliserida terhadap apoB $>8.8$ (bila menggunakan satuan $\mathrm{mg} / \mathrm{dl}$ ) menggambarkan peningkatan kilomikron. Penyebab utama peningkatan kilomikron adalah adanya penurunan aktivitas lipoprotein lipase (LPL). Penurunan aktivitas LPL ini dapat terjadi karena defisiensi LPL familial, atau defisiensi apoprotein C yang merupakan kofaktor LPL. Peningkatan VLDL dapat tergambar oleh peningkatan LDL dan apoB. Penurunanan aktivitas lipoprotein lipase pada PMH tidak sepenuhnya terganggu karena masih ada kilomikron remnant yang terbentuk dan free fatty acid (FFA) di hepar sehingga terjadi peningkatan VLDL dan peningkatan apoB., ${ }^{6,7}$

Parameter lain seperti SGOT, SGPT, ureum, dan kreatinin tidak dapat dikeluarkan karena sampel yang sangat lipemik menyebabkan interferensi yang signifikan baik menggunakan Alat $A B X$ Pentra 400 maupun Cobas 6000 Roche. Kedua alat ini menggunakan metode spektrofotometer. Metode spektrofotometer merupakan metode yang 
paling sering mengalami interferensi akibat sampel lipemik.

Absorbsi cahaya meningkat pada panjang gelombang yang lebih rendah sehingga pemeriksaan parameter tertentu yang menggunakan panjang gelombang yang lebih rendah akan lebih terpengaruh oleh sampel yang lipemik. Parameter SGOT, SGPT, ureum dan kreatinin mengalami interferensi yang signifikan karena SGOT, SGPT, dan ureum diukur pada panjang gelombang $340 \mathrm{~nm}$, dan kreatinin diukur pada gelombang $510 \mathrm{~nm}^{13}$

Interferensi akibat sampel lipemik dapat berbeda pada setiap alat pemeriksaan kimia klinik, meskipun menggunakan metode yang sama. Penelitian mengenai interferensi yang terjadi pada alat ABX Pentra 400 belum dilaporkan, namun pabrik menunjukkan limitasi interferensi pada kadar trigliserida di atas $437.5 \mathrm{mg} / \mathrm{dl}$ untuk parameter SGOT dan SGPT, dan di atas $612.5 \mathrm{mg} / \mathrm{dl}$ untuk parameter ureum dan kreatinin. Pabrik alat Cobas 6000 Roche menyatakan bahwa bias hasil pemeriksaan SGOT dan SGPT pada kadar trigliserida $150 \mathrm{mg} / \mathrm{dl}$, Ureum pada kadar trigliserida $1000 \mathrm{mg} / \mathrm{dl}$, dan kreatinin pada kadar trigliserida $800 \mathrm{mg} / \mathrm{dl}$ adalah di bawah $10 \%$. Hal ini sesuai dengan penelitian Ji dkk yang menunjukkan bahwa interferensi yang tidak signifikan pada pemeriksaan SGOT, SGPT, ureum dan kreatinin sesuai kadar batas trigliserida dinyatakan oleh pabrik. ${ }^{13,17}$

Studi Nikolak dkk mengenai interferensi pada alat Cobas 6000 Roche yang menunjukkan hal yang serupa yaitu bias hasil SGOT dan SGPT pada kadar trigliserida $100 \mathrm{mg} / \mathrm{dl}$ adalah di bawah $10 \%$, namun bias yang sangat jelas tampak pada kadar trigliserida $300 \mathrm{mg} / \mathrm{dl}$ yakni berupa penurunan palsu lebih dari 50\%. Studi ini juga menunjukkan bahwa pemeriksaan ureum dan kreatinin pada kadar trigliserida $1000 \mathrm{mg} / \mathrm{dl}$ menunjukkan bias di bawah $10 \%$ sebagaimana yang dinyatakan oleh pabrik. Penelitian yang mengukur ureum dan kreatinin pada kadar trigliserida di atas $1000 \mathrm{mg} / \mathrm{dl}$ belum dilakukan sehingga bias yang lebih besar masih sangat mungkin terjadi. ${ }^{13,18}$

Adanya interferensi yang sangat besar ini menyebabkan hasil keempat parameter tersebut tidak dapat dikeluarkan. Metode yang dapat dilakukan dalam menangani sampel lipemik adalah 1) Penggunaan ultrasentrifus untuk memisahkan lipoprotein berdasarkan densitasnya 2) Ekstraksi menggunakan larutan polar, dan 3) Pengenceran sampel menggunakan larutan salin. Penanganan sampel lipemik pasien ini menggunakan ultrasentrifus tetapi karena kadar trigliserida sampel di atas $1000 \mathrm{mg} / \mathrm{dl}$ (batas intereferensi alat Cobas 6000 Roche) maka hasil laboratorium tetap tidak dapat dikeluarkan oleh laboratorium rujukan. ${ }^{13}$

Studi Calmarza dkk membandingkan 15 parameter (glukosa kolesterol, trigliserida, bilirubin total, SGOT, SGPT, ureum, kreatinin, total protein, ALP, GGT, kalsium, fosfor, asam urat dan laktat dehidrogenase) yang diukur sebelum dan sesudah dilakukan ultrasentrifus menunjukkan bahwa terdapat perbedaan antara hasil sebelum dan sesudah dilakukan ultrasentrifus di bawah $6 \%$ pada hampir seluruh parameter kecuali kolesterol, trigliserida, dan SGPT. Meskipun begitu, analisis perbandingan secara statistik menunjukkan perbedaan yang signifikan pada semua parameter kecuali bilirubin total, glukosa, GGT, dan SGOT.

Solusi pada pasien ini adalah pemeriksaan ulang setelah penanganan profil lipid atau pemeriksaan parameter lain yang dapat menggambarkan fungsi yang sama dengan menggunakan metode lain yang menunjukkan interferensi yang minimal misalnya metode imunologi. ${ }^{14}$

Primary Mixed Hyperlipidemia merupakan penyakit autosomal dominan, namun pemeriksaan profil lipid orang tua pasien menunjukkan hasil yang tidak signifikan sehingga diduga kelainan metabolisme lipid pada pasien bukan merupakan turunan namun karena adanya mutasi genetik.

Sampel lipemik dapat menginterferensi pemeriksaan imunologik terutama metode nefelometri dan turbidimetri, akibat gangguan pada transmisi cahaya. Sampel lipemik dapat menyebabkan interferensi terhadap reaksi antigen antibodi sehingga dapat menyebabkan peningkatan palsu maupun penurunan palsu. Interferensi ini banyak dilaporkan pada pemeriksaan hormon endokrin seperti pemeriksaan Free tiroxin (FT4), estrogen, testosteron, dll. Interferensi pada metode imunologi yang lain seperti Enzyme Linked Fluorescent Assay (ELFA) belum dilaporkan., ${ }^{2,13,19}$

Pemeriksaan imunologis pada kasus ini menggunakan metode ELFA dan menununjukkan peningkatan antibodi IgG terhadap Citomegalovirus (CMV) pada pasien dan ibunya yaitu $28 \mathrm{IU} / \mathrm{ml}$ dan $20 \mathrm{IU} / \mathrm{ml}$. Interferensi sampel lipemik terhadap metode ini belum dilaporkan sehingga dapat disimpulkan bahwa pemeriksaan imunologi pasien tidak mengalami interferensi. Selain itu, pemeriksaan imunologis ibu dengan sampel serum ibu dalam kondisi baik memberi petunjuk yang cukup membantu dalam melihat adanya kemungkinan infeksi intrauterin.

Hasil pemeriksaan imunologi ini menunjukkan peningkatan antibodi IgG CMV pada bayi dan Ibunya. Peningkatan IgG CMV pada bayi 
dapat disimpulkan sebagai transmisi antibodi maternal. ${ }^{20,21}$

Penegakan diagnosis infeksi CMV masih sulit disimpulkan karena gejala klinis belum menunjukkan adanya infeksi CMV dan penelusuran hasil laboratorium lainnya seperti kultur virus belum dilakukan dan parameter lain yang masih sulit dilakukan karena karena interferensi sampel lipemik. Oleh karena itu, disarankan penelusuran lebih lanjut setelah parameter lain dapat dilakukan.

Hipertrigliseridemia berat sangat beresiko pada terjadinya pankreatitis. Resiko ini dinilai substasial bila kadar trigliserida $>10 \mathrm{mmol} / \mathrm{l}$ atau $>885 \mathrm{mg} /$ dl. Mekanisme yang mendasari terjadinya pankreatitis adalah akumulasi kilomikron pada pembuluh darah pankreas yang menyebabkan terjadinya lipolisis oleh enzim lipase pankreas yang diikuti dengan akumulasi FFA yang bersifat sitotoksik pada sel asini sehingga terjadi mikrotrombi, iskemia, dan nekrosis jaringan pankreas.

Diet total terhadap asupan lemak sangat dianjurkan karena penurunan konsumsi lipid akan menurunkan akumulasi kilomikron dan trigliserida dalam darah. Suplemen vitamin larut dalam lemak dan obat penurun lipid juga dapat memperbaiki prognosis dan mencegah komplikasi. Pada kasus ini, pasien belum melanjutkan pengobatan sehingga belum dapat dipantau penurunan trigliserida dan kolesterol serumnya. ${ }^{6,11}$

Diagnosis banding yang paling mendekati Primary Mixed Hyperlipidemia adalah Familial Chylomicronemia (Hiperlipidemia Frederickson tipe I). Kedua tipe menunjukkan sampel serum yang lipemik, kadar trigliserida sangat tinggi $>1000 \mathrm{mg} / \mathrm{dl}$ dan gejala klinis yang juga hampir sama, tetapi pada Familial Chylomicronemia terjadi peningkatan kilomikron tanpa disertai peningkatan VLDL sebagaimana pada $\mathrm{PMH}$, sehingga nilai LDL dan apo B biasanya rendah atau normal. ${ }^{6,22}$

\section{SIMPULAN}

Sampel lipemik dapat menginterferensi berbagai metode pemeriksaan laboratorium. Hasil laboratorium dengan interferensi sampel lipemik ini perlu diinterpretasi secara kritis dan tepat sehingga dapat menunjang diagnosis dan penanganan pasien yang tepat pula.

\section{KONFLIK KEPENTINGAN.}

Pada penelitian ini peneliti tidak memiliki konflik kepentingan dengan pihak manapun dalam melakukan penelitian.

\section{PENDANAAN PENELITIAN}

Semua biaya penelitian ditanggung oleh biaya mandiri tanpa bantuan dari pihak sponsor manapun

\section{KONTRIBUSI PENULIS}

Perancangan desain penelitian, pengambilan data, analisis penelitian, menulis penelitian, melaksanakan editing, melakukan dan mengirimkan naskah hingga terbitnya tulisan ini dilakykan secara bersama oleh seluruh penulis dalam laporan penelitian ini.

\section{DAFTAR PUSTAKA}

1. Andrade NN, Souza CL. Procedures to minimize interference hypertriglyceridemia in laboratory exams of lipemic samples in acute pancreatitis : a case report. J Bras Patol Med Lab. 2016; 52(2): 103 - 106.

2. Kroll MH and Mccudden CR. Endogenous Interference Clinical Laboratory Test Icteric, Lipemic, and Turbid Samples Boston: Walter de Gruyter; 2012: 35 - 45.

3. Mainali S, Davis SR and Krasowski MD. Frequency and causes of lipemia interference of clinical chemistry laboratory tests. Pract Lab Med. 2017; 8: 1 - 9 .

4. Stroes E, Moulin P, Parhofer KG, Rebours V, Lohr JM, Averna M. Diagnostic algorithm for familial chylomicronemia syndrome. Atheroscler Suppl. 2017; 23: 1 - 7 .

5. Brahm A, Hegele RA. Hypertriglyceridemia. Nutrients. 2013; 5(3): 981 - 1001

6. Sniderman A, Couture P, De Graaf J. Diagnosis and treatment of apolipoprotein B dyslipoproteinemias. Nat Rev Endocrinol. 2010; 6(6): 335 - 46.

7. Matera D, Seydewitz H, Niederhoff H, Wiebusch $\mathrm{H}$ and Brandis M. Dyslipidaemia in a boywith recurrent abdominal pain, hypersalivation and decreased lipoprotein lipase activity. Europe Journal Pediatrics. 1996:660-664.

8. Nagasaka H, Kikuta H, Chiba H, Murano T, Hiroshima H, Ohtake A et al. Two cases with transient lipoprotein lipase (LPL) activity impairment: evidence for the possible involvement of an LPL inhibitor. Eur J Pediatr. 2003; 162(3): 132 - 138.

9. Remaley AT, Rifai N, Warnick GS. Lipids, Lipoproteins, Apolipoproteins, and Other Cardiovascular Risk Factors. In: Burtis CA, Bruns DE. (eds.) Tietz Textbook of Clinical Chemistry and Molecular Diagnostics. United States of America: Elsevier Saunders; 2012: 775 - 778.

10. Sapountzi P, Lopez N, Almeda FQ. Lipid Disorder. In: P. M. Camacho. (ed.) A Color Handbook Clinical Endocrinology and Metabolism. UK: Manson Publishing; 2011: 169 - 187.

11. Semenkovich CF, Goldberg AC, Gallagher IJ. Disorder of Lipid Metabolism. In: S Melmed, KS Polonsky, PR Larsen, HM Kronenberg. (eds.) William Textbook of Endocrinology. 12th ed. Philadelpia: Elsevier Saunders; 2011: 1650-1653.

12. Sriram CS, Gulati SF, Chopra V, Vashist S, Menon PS. Familial combined hyperlipidemia in a North Indian kindred. Indian J Pediatr. 2005; 72(11):987-9.

13. Nikolac N. Lipemia : causes, interference mechanism, detection, and management. Biochem Med (Zagreb). 2014; 24(1):57-67.

14. Calmarza P, Cordero J. Lipemia interferences in routine clinical biochemical tests. Biochem Med (Zagreb). 2011; 21(2): 160-6.

15. Smock KJ, Perkins SL. Examination of the Blood and Bone Marrow. In: JP Greer, DA Arber, B Glader. (eds.) Wintrobe's Clinical Hematology. 13th ed. China: Wolters Kluwers Health; 2014: $1-5$. 
16. Wellen KE, Hotamisligil GS. Inflammation, stress, and diabetes. J Clin Invest. 2005; 115(5): 1111 - 9.

17. Ji JZ, Meng QH. Evaluation of the interference of hemoglobin, bilirubin, and lipids on Roche Cobas 6000 assays. Clin Chim Acta. 201; 412 (17-18): 1550-3.

18. Nikolac N, Simundic A, Miksa M, Lima-Oliveira G, Salvagno GL, Caruso B, Guidi GC. Heterogeneity of manufacturers' declarations for lipemia interference - an urgent call for standardization. Clin Chim Acta. 2013; 426: $33-40$.

19. Schiettecatte J, Anckaert E, Smitz J. Interferences in Immunoassays. Advances in Immunoassay. Available at: http://www.intechopen.com/books/advances-inimmunoassay-technology/interference-in-immunoassays [Accessed April 2018]

20. Bannister B, Gillespie SH, Jones J. Congenital and Perinatal Infections. In: Infection Microbiology and Management. 3rd ed. Australia: Blackwell Publishing; 2006: 344-358.
21. Demmler GJ. Cytomegalovirus. In: J Fletcher and $\mathrm{M}$ Dudlick. (eds.) Feigin \& Cherry's Textbook of Pediatric Infectious Diseases. United States of America: Saunders Elsevier; 2009: 2023-2037.

22. Berglund L, Brunzell JD, Goldberg AC, Goldberg IJ, Sacks F, Murad $\mathrm{MH}$ et al. Evaluation and treatment of hypertriglyceridemia : an Endocrine Society clinical practice guideline. J Clin Endocrinol Metab. 2012; 97(9):2969-89.

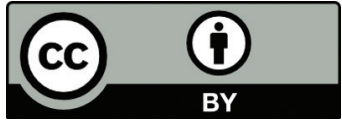

This work is licensed under a Creative Commons Attribution 